\title{
REVIEW OF SOME EUPHORBIACEAE PLANTS IN USADA TARU PRAMANA AND ITS PHARMACOLOGICAL ACTIVITIES
}

\author{
I Gede Bangkit Adi Sentosa ${ }^{1}$, I Kadek Suardiana ${ }^{1}$, A.A Gede Rai Yadnya Putra ${ }^{1 *}$ \\ ${ }^{1}$ Department of Pharmacy, Faculty of Mathematics and Science, Udayana University \\ Corresponding author email: agungryp@unud.ac.id
}

\begin{abstract}
Background: World Health Organization (WHO) states that up to $65 \%$ of the world's population uses traditional medicines. Indonesia is one of the countries where most people still use traditional medicine, especially in Bali. The traditional Balinese plant-based medical system that has existed for a long time and is still inherited today is Usada Taru Pramana. One of the many plants found in Usada Taru Pramana is the Euphorbiaceae. Objective: This work aims to review some of the Euphorbiaceae plants written in Usada Taru Pramana, which have a variety of potential pharmacological activities. Method: This article review using a primary and secondary data sources. Results: Some parts of the Euphorbiaceae plants in Usada Taru Pramana contain important phytochemical constituents such as phenols, alkaloids, flavonoids, saponins, tannins and essential oils. Some of the potential pharmacological activities that have been tested are anti-inflammatory, analgesic, and antibacterial. Conclusion: The Euphorbiaceae plants in Usada Taru Pramana have a variety of phytochemical constituents and correlates with its pharmacological activities. Further research needs to be conducted to explore other Euphorbiaceae plants species in Usada Taru Pramana to find compounds and other pharmacological activities to deal with various diseases in the community.
\end{abstract}

Keywords: Usada Taru Pramana, Euphorbiaceae, Phytochemical Constituents, Pharmacological Activities.

\section{INTRODUCTION}

World Health Organization (WHO) states that up to $65 \%$ of the world's population uses traditional medicines and medicines from natural ingredients (Kemenkes RI 2007) $^{[1]}$. Indonesia is one of the countries where most people still use traditional medicine and have a variety of traditional medical systems based on natural ingredients, especially in Bali. The use of plant-based medicines is a popular approach to health care in Indonesia, especially Bali. The traditional Balinese plant-based medical system that has existed for a long time and is still inherited today is Usada Bali. Usada is a term for the Balinese system of treatment written on papyrus with Balinese language and script and compiled into a text of medical knowledge, how to concoct medicine, how to treat or treat traditionally or traditional Balinese medicine ${ }^{[2]}$. The word Usada comes from the word ausadhi (Sanskrit), which means plants that contain medicinal properties. There are various types of Lontar Usada, one of which is Lontar Usada Taru Pramana. Taru pramana is derived from the word "taru", meaning plant and "premana" means strength or efficacy. Usada Taru Pramana is a papyrus that tells the plants to come to $\mathrm{Mpu}$ Kuturan to express their respective properties that can be used as medicines ${ }^{[3]}$. Usada Taru Pramana contains a description of the method of treatment 
(usada) in the form of dialogue in the disclosure of how to treat $\mathrm{it}^{[4]}$. Parts of plants that can be used in medicine are from the leaves, flowers, fruits, seeds, bark, sap, roots, rhizomes and all parts of the plant.

Usada Taru Pramana consists of approximately 182 plants with diverse properties and uses. These plants come from various family, including Liliaceae, Fabaceae, Moraceae, Lauraceae, Asteraceae, Piperaceae, Zingiberaceae, Euphorbiaceae, and others. One of the many plants found in Usada Taru Pramana is the Euphorbiaceae. Euphorbiaceae is a large family of flowering plants with about 300 genera and 8.000 species. This allows the Euphorbiaceae plants to be the largest plant with many species. The implication is that there is a higher chance that some species of plants will have medicinal properties. Most Euphorbiaceae plants are herbaceous, but several other species are found as shrubs or trees in the tropics ${ }^{[5,6]}$. The distribution of Euphorbiaceae plants spread in the territory of Indonesia, Malaysia, and America. Some Euphorbiaceae plants are written in Usada Taru Pramana such as cat tail (Acalypha hispida), buni (Antidesma bunius), jarak (Ricinus communis), candlenut (Aleuritus mollucana), and others ${ }^{[7,8]}$. Traditionally, the Euphorbiaceae plants are used to treat eye pain, dizziness, plaque, thrush, sore throat, and pain throughout the body.

The Euphorbiaceae plants have been widely used as traditional medicine by various methods of treatment. However, scientific evidence is needed to ensure that the Euphorbiaceae plants are scientifically proven to have healing activity. In this review, we have summarized some of the Euphorbiaceae plants in Usada Taru Pramana along with some phytochemical compounds and pharmacological activities. The existence of scientific evidence from several studies is expected to further convince the public that the plants contained in Usada Taru Pramana do have pharmacological activities and are beneficial to health.

\section{METHODS}

This primary data source was obtained from the derivation of Usada Taru Pramana papyrus by Putra (1999) ${ }^{[8]}$. This process of finding secondary data sources is obtained by searching on google, google scholar, and NCBI with the keywords "phytochemical constituents of Acalypha hispida, Antidesma bunius, Ricinus communis, Jatropha curcas, Pedilanthus tithymaloides, Aleurites moluccana, and Sauropus androgynus" and "pharmacological activities of Acalypha hispida, Antidesma bunius, Ricinus communis, Jatropha curcas, Pedilanthus tithymaloides, Aleurites moluccana, and Sauropus androgynus". Secondary data sources used are journals that have been published for the past ten years. The use of data over the last ten years is applied of no last ten years of data is supported.

\section{RESULTS}

The result obtained from the primary data source in the form of derivation Usada Taru Pramana is several Euphorbiaceae plants and the plant's parts used. The phytochemical constituents and pharmacological activities were obtained from the various data source in this review. The result obtained from the primary data source is listed in Table 1.

\section{DISCUSSION}

\section{Acalypha hispida}

In Usada Taru Pramana, the Acalypha hispida plant or ekor kucing is known as a crop of white langurs and has efficacy as an eye remedy. Ekor kucing plus onions and fennel are then ground, filtered, and precipitated as an eye medicine. 
Table 1. Some Euphorbiaceae Plants in Usada Taru Pramana and Its Phytochemical Constituents and Pharmacological Activities

\begin{tabular}{|c|c|c|c|c|}
\hline No & Species & Parts & $\begin{array}{l}\text { Phytochemical } \\
\text { Constituents }\end{array}$ & $\begin{array}{c}\text { Pharmacological } \\
\text { Activities }\end{array}$ \\
\hline 1 & Acalypha hispida & Leaves $^{[7,8]}$ & $\begin{array}{c}\text { Phenol compounds, } \\
\text { flavonoids, glycosides, } \\
\text { steroids, saponins, } \\
\text { hydroxyantraquinones, gallic } \\
\text { acid, corilagin, and } \\
\text { triterpenoids }^{[11]}\end{array}$ & $\begin{array}{c}\text { Antibacterial, } \\
\text { Antioxidant }{ }^{[12,13,14,15]}\end{array}$ \\
\hline 2 & Antidesma bunius & $\begin{array}{l}\text { Leaves, } \\
\text { Fruits, } \\
\text { Roots, } \\
\text { Barks }^{[7,8]}\end{array}$ & $\begin{array}{l}\text { Polyphenols, terpenoids, } \\
\text { glucoside, saponins, tannins, } \\
\text { biflavonoids, anthocyanins, } \\
\text { luteolin, rutin, resveratrol, } \\
\text { and quercetin } \\
\text { a16,17] }\end{array}$ & $\begin{array}{l}\text { Antiinflammation, } \\
\text { Antibacterial }^{[18,19]}\end{array}$ \\
\hline 3 & Ricinus communis & $\begin{array}{l}\text { Leaves, } \\
\text { Roots }^{[7,8]}\end{array}$ & $\begin{array}{l}\text { Steroids, saponins, alkaloids, } \\
\text { flavonoids, and glycosides }{ }^{[20]}\end{array}$ & $\begin{array}{l}\text { Antiinflammation, } \\
\text { Antinociceptive, } \\
\text { Analgesic } \\
21,22,23]\end{array}$ \\
\hline 4 & Jatropha curcas & $\begin{array}{l}\text { Roots, } \\
\text { Latex }^{[7,8]}\end{array}$ & $\begin{array}{l}\text { Phenols, tannins, free amino } \\
\text { acids and phytic acid }\end{array}$ & $\begin{array}{l}\text { Antiinflammation, } \\
\text { Wound Healing, } \\
\text { Antibacterial }^{[25,26]}\end{array}$ \\
\hline 5 & $\begin{array}{l}\text { Pedilanthus } \\
\text { tithymaloides }\end{array}$ & Leaves $^{[7,8]}$ & $\begin{array}{c}\text { Alkaloids, flavonoids, } \\
\text { terpenoids, phenols, tannins, } \\
\text { saponins, glycosides, sterols, } \\
\text { and amino acids }{ }^{[27]}\end{array}$ & $\begin{array}{l}\text { Antiinflammation, } \\
\text { Antinociceptive } \\
\text { [28,29] }\end{array}$ \\
\hline 6 & $\begin{array}{l}\text { Aleurites } \\
\text { moluccana }\end{array}$ & $\begin{array}{l}\text { Seeds, } \\
\operatorname{Bark}^{[7,8]}\end{array}$ & $\begin{array}{l}\text { Alkaloids, polyphenols, } \\
\text { flavonoids, coumarin, } \\
\text { tannins, steroids, and } \\
\text { triterpenoids }^{[30]}\end{array}$ & $\begin{array}{c}\text { Antibacterial, } \\
\text { Antinociceptive }^{[31,32,33]}\end{array}$ \\
\hline 7 & $\begin{array}{l}\text { Sauropus } \\
\text { androgynus }\end{array}$ & Leaves $^{[7,8]}$ & $\begin{array}{l}\text { Sterols, resins, tannins, } \\
\text { saponins, alkaloids, } \\
\text { flavonoids, terpenoids, } \\
\text { glycosides, phenols, cardiac } \\
\text { glycosides, and acidic } \\
\text { compounds }^{[34]}\end{array}$ & $\begin{array}{l}\text { Antiinflammation, } \\
\text { Antibacterial, Anti- } \\
\text { obesity }{ }^{[35,36,37,38]}\end{array}$ \\
\hline
\end{tabular}

The eye disease in question is conjunctivitis caused by a bacterial infection. In general, the bacteria that cause conjunctivitis are Gram-positive and Gram-negative bacteria. Examples of Gram-positive bacteria are Staphylococcus aureus, Staphylococcus epidermidis, Streptococcus pneumonia, and Streptococcus viridians and examples of Gram-negative bacteria are Escherichia coli, Pesudomonas aeruginosa, Klebsiella pneumonia, Serratia marcescens, Proteus sp., andEnterobacterus sp. ${ }^{[9,10]}$.

Phytochemical screening of water and methanol extracts of plant leaves showed the presence of phenol compounds, flavonoids, glycosides, steroids, saponins, phlacacin, and hydroxyantraquinones. Isolated compounds from plants include gallic acid, corilagin, triterpenoids, flavonoids such as quercetin and kaempferol derivatives ${ }^{[11]}$. The leaves of Acalypha hispida are reported to contain several phytochemical compounds and have antibacterial activity. Acalypha hispida leaf extract contains carbohydrates, cardiac glycosides, anthraquinone glycosides, tannins, alkaloids, steroids, saponins, and flavonoids.

The methanol extract of Acalypha hispida leaves inhibits more bacteria than other extracts of Acalypha hispida solvents such as ethanol, chloroform, and water. In testing the antibacterial activity by the Kirby-Bauer agar diffusion method, the ethanol extract of the leaves of Acalypha hispida with a concentration of $80 \%$ has the highest antibacterial activity than the 
other extracts, producing a diameter of inhibition zone of $18,50 \mathrm{~mm}$ in Escherichia coli bacteria and $19,33 \mathrm{~mm}$ in Staphylococcus aureus ${ }^{[12,13]}$. Other studies report that the methanol extract of Acalypha hispida leaves produces a minimum bactericidal concentration (MBC) against Pseudomonas aeruginosa, Staphylococcus aureus, and Salmonella typhi with each MBC of $250 \mathrm{mg} / \mathrm{mL}$. All extracts were able to kill Escherichia coli bacteria, but methanol extract produced the lowest $\mathrm{MBC}$ of $125 \mathrm{mg} / \mathrm{mL}$ while other solvent extracts produced MBC 250 $\mathrm{mg} / \mathrm{mL}$. This shows that the methanol extract of Acalypha hispida leaves has stronger antibacterial effectiveness compared to other extract solvents and is more effective against Escherichia coli bacteria compared to other bacteria ${ }^{[14,15]}$.

Other studies report the presence of antioxidant activity in the extract of Acalypha hispida leaves. The results of antioxidant activity testing using the Water Soluble Tetrazolium Salt-1 (WST-1) reduction method showed that the ethanol extract of Acalypha hispida leaves had antioxidant activity (SOD like activity) with the percentage of inhibition at a concentration of $10 \mu \mathrm{g} / \mathrm{mL}, 100 \mu \mathrm{g} / \mathrm{mL}$, and $1000 \mu \mathrm{g} / \mathrm{mL}$, which is $11,27 \%$, $15,20 \%$ and $22,06 \%$. Ethanol extract fraction of Acalypha hispida leaves which has the best antioxidant activity (SOD-like activity) is ethyl acetate fraction with inhibition percentage at concentrations of $10 \mu \mathrm{g} / \mathrm{mL}, 100 \mu \mathrm{g} / \mathrm{mL}$, and $1000 \mu \mathrm{g} / \mathrm{mL}$, which is equal to $63,14 \%, 91,95 \%$ and $100 \%{ }^{[12]}$. The antioxidant activity can be related to secondary metabolites found in Acalypha hispida, namely flavonoids and phenols.

\section{Antidesma bunius}

Leaf, fruit, root, and bark Antidesma bunius contains polyphenols, terpenoids, glucoside, saponins, tannins, biflavonoids, anthocyanins, luteolin, rutin, resveratrol, quercetin, procyanidin, catechins, amentoflavone, corinagines (1-O-galloyl) $3,6-\mathrm{O}-\mathrm{hexahydroxydiphenoyl- \beta -}$

glucopyranoside), gallic acid (3,4,5trihydroxybenzoic), elagic acid, vicinin II, ferulic acid, citric acid, benzoic acid, malic acid, lactic acid, oxalic acid, acetic acid, ascorbic acid, and caffeic acid ${ }^{[16]}$.

The methanol extract of Antidesma bunius leaves contains saponins, tannins, flavonoids, steroids, phlobatin, coumarin, alkaloids, emodin, and anthraquinones ${ }^{[17]}$. Antidesma bunius leaf extract also has antiinflammatory and antibacterial activity. Anti-inflammatory measurement was carried out by looking at the ability of Antidesma bunius leaf extract to reduce swelling in the legs of experimental animals which were injected with $1 \%$ carrageenan solution. After being injected with carrageenan, the rat showed swelling and redness in the legs, and the mouse could not walk nimbly as before injection. The principle in this method is to measure the volume of the swollen sole of a test animal that has been induced by an inflammatory agent. Ethanol extract and ethyl acetate fraction of Buni leaves (Antidesma bunius) have effective antiinflammatory activity at a dose of 200 $\mathrm{mg} / \mathrm{kg}$ body weight. Antiinflammatory effect of leaf extract Antidesma bunius showed the most effective activity to reduce oedema in rat feet, ethanol extract $200 \mathrm{mg} / \mathrm{kg}$ body weight and ethyl acetate fraction $200 \mathrm{mg} / \mathrm{kg}$ body weight showed the same value to positive control namely sodium diclofenac. The anti-inflammatory effect is thought to be caused by the activity of secondary metabolites found on the leaves of Antidesma bunius, namely flavonoids, triterpenoid steroids, glycosides, and saponins ${ }^{[18]}$.

Antidesma bunius fruit has the potential for antibacterial activity especially against Gram-positive bacteria such as Bacillus cereus and Gram-negative bacteria such as Salmonella thypimurium. It is known that the inhibitory power is strong (at extract concentrations of $80 \%$ ), 
moderate (at concentrations of $40 \%$ ), and low (at concentrations of 10-1,25\%) against the Bacillus cereus. Whereas against test bacteria Salmonella Typhimurium is strong inhibitory (at concentrations of 80 and $40 \%$ ) and low (at concentrations of 20-1,25\%). The average diameter of inhibition zone formed in the fruit extract of Antidesma bunius against Bacillus cereus bacteria at a concentration of $80 ; 40 ; 20 ; 10 ; 5 ; 2,5$; and $1,25 \%$ each was $18, .4 ; 12 ; 9,4 ; 8,4 ; 7,4 ; 7$; and $6,4 \mathrm{~mm}$, while against Salmonella Typhimurium at a concentration of $80 ; 40 ; 20 ; 10 ; 5 ; 2,5$; and $1,25 \%$ respectively of 26,$7 ; 21 ; 11 ; 10 ; 8$; 7 ; and $4,3 \mathrm{~mm}^{[19]}$.

\section{Ricinus communis}

Phytochemical studies of Ricinus communis show the presence of steroids, saponins, alkaloids, flavonoids, and glycosides. The dried leaf of Ricinus communis shows alkaloid content, ricinin $(0,55 \%)$, glucopyranoside, kaempferol-3-ODquercetin, glucopyranoside, xylopyranoside quercetin-3-O-Dcamphor, $\quad \alpha$ sesquiterpenoid ( $\beta$-caryophyllene), quercetin gallic acid, gentisic acid, routine, and epicatechin. Indole-3-acetic acid has been extracted from the root. The seeds contain $45 \%$ glycosides from ricinoleic acid, isoricuric acid, stearic acid and dihydroxysteine, lipase and ricinin. GLC studies of castor oil showed palmitic acid $(1,2 \%)$, stearic acid $(0,7 \%)$, oleic acid $(3,2 \%)$, linoleic acid $(3,4$ ricinoleate $(89,4 \%)$ and dihydroxy stearic. GC-MS analysis of Ricinus communis showed several compositions of essential oils such as cineol $(30,98 \%)$, $\alpha$-pinene $(16,88 \%)$, camphor and lupeol ${ }^{[20]}$.

Leaf extract of Ricinus communis has an inflammatory activity based on the potential anti-inflammatory test using paw carrageenan oedema for acute inflammation testing in Wistar rats. In the carrageenan-induced paw oedema model, subplantar carrageenan administration resulted in significant paw oedema formation compared to normal paw at consecutive hours of up to 24 hours. The methanol extract of the leaves of Ricinus communis $(250$ and $500 \mathrm{mg} / \mathrm{kg}$ body weight) each showed a cellular protective effect during the formation of oedema and in all stages of acute inflammation. This effect is supported by the protective effect of flavonoids against carrageenan-induced foot oedema in rats ${ }^{[21]}$.

In addition to anti-inflammatory activity, other studies report that the methanol extract of Ricinus communis leaves has antinociceptive and analgesic activity. The methanol extract of $R$. communis leaves reduced the writhing of acetic acid-induced rats significantly at doses of 100,125 and $150 \mathrm{mg} / \mathrm{kg}$ body weight. The ethanol extract of the leaves of Ricinus communis showed analgesic effects in phase I and phased II pain that was formalin-induced. Each phase is associated with neurogenic and inflammatory pain. The methanol extract of Ricinus communis leaves inhibits a significant dose-dependent neurogenic and inflammatory phase. The methanol extract of Ricinus communis leaves at a dose of $150 \mathrm{mg} / \mathrm{kg}$ body weight showed significant inhibition of neurogenic and inflammatory phases $(\mathrm{p}<0,001)$ which was comparable to standard drugs (diclofenac). The mechanism of the analgesic effect of the methanol extract of Ricinus communis leaves is caused by the inhibitory effect or release of endogenous substances which induce nerve endings of pain similar to NSAIDs $^{[22,23]}$.

\section{Jatropha curcas}

Phytochemical analysis of various parts of Jatropha plant revealed variations in the total content of phenols, tannins, free amino acids and phytic acid. The leaves contain phenols, tannins, and free amino acids $^{[24]} .15 \%$ latex of Jatropha curcas has anti-inflammatory activity potential because it can accelerate the healing 
process of the inflammatory phase of the wound. The results showed that the cream of $10 \%$ and $15 \%$ latex of Jatropha curcas stimulated a moderate immune reaction against CD68 in wound healing. These extracts show good antioxidant, coagulant and anticoagulant, analgesic, and antiinflammatory properties. Similar results were observed for the effect of n-hexane leaf extract of Jatropha curcas, which showed a hemostatic effect and a significant reduction in bleeding time. Latex from tree branches has been used in healing wounds, refractory lesions, and septic gums and as a barrier to bruising. There are several secondary metabolic compounds extracted from the leaves of Jatropha curcas, which are involved in the wound healing process. Jatropha curcas leaves and sap extracts contain a considerable amount of phenolic compounds and saponins which are responsible for antimicrobial and antioxidant activity. Quercetin and routine flavonoids can enhance the wound healing process in the early phase, that is, regulation of expression of vascular endothelial growth factor (VEGF) for the growth of new blood vessels and the formation of type III collagen. However, flavonoid compounds play a role in the initial phase of wound healing (the inflammatory phase) to increase the activity of the immune system such as interleukin-2, lymphocyte proliferation, and macrophages. In addition, sesquiterpenoids are responsible for antimicrobial and analgesic effects. Meanwhile, proteins such as curcaine are responsible for wound healing. Jatropha curcas leaves and sap contain phenolic compounds and saponins which have antioxidant and anti-inflammatory activity. Flavonoids as antioxidants can reduce free radicals and will bind to free radicals that damage cell membranes. Flavonoids that accumulate in latex Jatropha curcas play an important role in the inflammatory phase by increasing interleukin-2, lymphocyte proliferation, and macrophages. Saponins can increase monocyte proliferation which will ultimately increase the number of macrophages that secrete growth factors that are important for the wound healing process $^{[25]}$.

Jatropha curcas leaf extract has the potential for antibacterial activity. The result of methanol extract of $J$. curcas leaves which use maceration method has inhibitory against Staphylococcus epidermidis at a concentration of $50 \mathrm{ppm}$ $(6,67 \mathrm{~mm})$ and is increasing at a concentration of $100 \mathrm{ppm}(19,33 \mathrm{~mm})$. Inhibition zone diameters in reflux Jatropha curcas leaves extracts showed inhibition in all concentration series. The smallest inhibition zone is shown at a concentration of $3,125 \mathrm{ppm}(9,33 \mathrm{~mm})$ and has positive colleration with increasing concentration. The biggest inhibition zone at a concentration of $100 \mathrm{ppm}$ was 22,67 $\mathrm{mm}$. Reflux extracts provide greater resistance than methanol maceration extracts against Staphylococcus. epidermidis and Staphylococcus aureus. The methanol extract of Jatropha curcas leaves resulting from maceration and reflux has strong antibacterial activity against both Staphylococcus epidermidis and Staphylococcus aureus but still below the standard antibiotic drug, such as clindamycin $^{[26]}$.

\section{Pedilanthus tithymaloides}

Phytochemical screening reveals the presence of alkaloids, flavonoids, terpenoids, phenols, tannins, saponins, glycosides, sterols, amino acids, kaempferol 3-O- $\beta$-D-glucopyranoside, quercitrin, isoquercitrin, and scopoletin. The relevant phytochemical groups are identified as steroids in hexane and ethyl acetate, triterpenes in hexane, tannins in ethyl acetate, coumarin in ethyl acetate and saponins in hexane and ethyl acetate $\operatorname{extract}^{[27]}$. 
Methanol and chloroform extracts of Pedilanthus tithymaloides leaves have antiinflammatory activity based on the results of inflammatory induction test of swollen feet with carrageenan. Methanol extract significantly reduced carrageenan-induced foot oedema after three hours of injection at all doses tested compared to the positive control group indomethacin $(\mathrm{p}<0,001)$. Significant reduction in feet oedema was also given by chloroform extract at doses of 200 and $400 \mathrm{mg} / \mathrm{kg}$ body weight compared to the positive control group indomethacin $(p<0,05)$. Methanol extract dose of $400 \mathrm{mg} / \mathrm{kg}$ body weight showed inhibition of oedema paw that was almost the same $(62,28 \%)$ as observed with the indomethacin group $(65,80 \%)$ whereas in chloroform extract with the same dose showed inhibition of $49,29 \%$ after five hours carrageenan injection. It is known that carrageenan-induced inflammatory reactions occur in two phases: the initial phase (0-2,5 hours after injection) resulting from the release of serotonin, bradykinin, and histamine, then the advanced phase is associated with the release of prostaglandins. Methanol and chloroform extracts of Pedilanthus tithymaloides leaves produced inhibition after the third hour of carrageenan-induced inflammation, showing a selective inhibitory effect on prostaglandin synthesis. The mechanism of anti-inflammatory activity of leaves of Pedilanthus tithymaloides is thought to originate from the blocking of synthesis and release of prostaglandins, which correlate naturally with therapeutic doses of most clinically effective antiinflammatory agents ${ }^{[28]}$.

Methanol and chloroform extracts also showed peripheral antinociceptive activity in the inflammatory pain model induced by acetic acid. Oral administration of methanol and chloroform extracts (100, 200 , and $400 \mathrm{mg} / \mathrm{kg}$ body weight) resulted in a reduction in the amount of writhing ( $p$ $<0,001)$ of $22 \%, 39,3 \%$, and $48,48 \%$, respectively and $36,36 \%, 66,67 \%$, and
$79,17 \%$ compared to the inhibition $(90,9 \%)$ produced by diclofenac sodium (10 mg/kg body weight). This nociceptive activity is associated with an increase in PGE2 and PGF2a levels in peritoneal fluid and inhibits synthesis of prostaglandin and cyclooxygenase $^{[29]}$.

\section{Aleurites moluccana}

Aleurites moluccana bark extract contains various phytochemical compounds such as alkaloids, polyphenols, flavonoids, coumarin, tannins, steroids, and triterpenoids. Various phytoconstituents such as flavonoids and triterpenes, hydrocarbons, sterols, amino acids and carbohydrates are present in the leaves of Aleurites moluccana. The methanol extract of Aleurites moluccana leaf showed the presence of two Cglycoside flavonoids namely Swertisin and 2-O-rhamnosylswertisin. A. moluccana seeds contain glycerides, fatty acids such as linoleic acid, palmitic acid, stearic acid, myristic acid, oils, proteins and vitamin $\mathrm{B}^{[30]}$.

The disk diffusion test results showed significant Aleurites moluccana extract activity against Gram-positive (Staphylococcus aureus and Streptococcus pyrogenes) and Gram-negative bacteria (Pseudomonas aeruginosa and Klebsiella pneumoniae). Results for MIC and MBC against Staphylococcus aureus showed the lowest MIC in acetonitrile bark extract (195 $\mu \mathrm{g} / \mathrm{mL}$ ) whereas Streptococcus pyogenes had the lowest MIC in methanol extract from the same bark $(781 \mu \mathrm{g} / \mathrm{mL})$. Pseudomonas aeruginosa showed very low MIC shown in methanol extracts of bark (98 $\mu \mathrm{g} / \mathrm{mL})$. Finally, for Klebsiella pneumoniae all extracts showed high MIC, but the lowest in the group was shown in cutaneous acetonitrile extract ${ }^{[31,32]}$.

The results of the isolation and identification of the methanol extract of Aleurites moluccana leaf showed two main flavones of C-glycosida, namely swertisin and 2-O-rhamnosylswertisin, which have 
potential antinociceptive activity. The antinociceptive pharmacological effect of A. moluccana extract was evaluated in a mechanical hypernociception model induced by flogistic agents such as carrageenan, PGE2, and CFA. Oral administration of Aleurites moluccana extract $(500 \mathrm{mg} / \mathrm{kg}$ body weight) can reduce mechanical hypernociceptive caused by carrageenan injection, with inhibition of $36 \pm 4 \%$ and ID50\% of 443 (400-490) $\mathrm{mg} / \mathrm{kg}$ body weight. Significant results were obtained with animals injected with CFA, which Aleurites moluccana extract dose $500 \mathrm{mg} / \mathrm{kg}$ body weight orally reduced the hypernociceptive threshold up to six hours after CFA injection, with $48 \pm$ $4 \%$ inhibition at $500 \mathrm{mg} / \mathrm{kg}$ doses. Aleurites moluccana extract, dose 125 to $500 \mathrm{mg} / \mathrm{kg}$ body weight, has been proven effective in preventing mechanical hypnosis from being induced by PGE2 for up to one hour after irritant injection. The reduction percentages are $26 \pm 10 \%$ and 33 $\pm 3 \%$, for 250 and $500 \mathrm{mg} / \mathrm{kg}$ body weight. Swerticin isolate compound and 2-Orhamnosylswertisin dose of $30 \mathrm{mg} / \mathrm{kg}$ body weight was effective in inhibiting the hypernociceptive response, when compared to the control group, with inhibitions of $70 \pm 2 \%$ and $50 \pm 5 \%$, respectively. Furthermore, 2-Orhamnosylswertisin is able to significantly inhibit mechanical sensitization induced by CFA or PGE2, with each inhibiting $25 \pm$ $3 \%$ and $94 \pm 6 \%[33]$.

\section{Sauropus androgynus}

Phytochemical detection of Sauropus androgynus leaves reveals the presence of sterols, resins, tannins, saponins, alkaloids, flavonoids, terpenoids, glycosides, phenols, catechols, cardiac glycosides, and acidic compounds such as phenolic acids, chlorogenic acid, caffeic acid, and ferric acid. Analysis of ethanol extract of Sauropus androgynus leaves using gas chromatography-mass spectrometry (GCMS) revealed the presence of phytols and squalene. Seven bioactive compounds from methanol extract from the aerial portion of Sauropus androgynus, including three lignans glycosides, a lignans glycosides, glycosides ${ }^{[34]}$.

The methanol, ethanol, and water extracts of Sauropus androgynus leaves contain bioactive compounds which have pharmacological properties and are responsible for anti-inflammatory activities such as tannins, flavonoids, alkaloids, phenols, and steroids. Leaves extract in doses of $200 \mathrm{mg} / \mathrm{kg}$ body weight and 400 $\mathrm{mg} / \mathrm{kg}$ body weight has resulted in a significant increase in heat plate reaction time in doses depending from 0 to 90 minutes compared to $100 \mathrm{mg} / \mathrm{kg}$ body weight. Leaf extract in both doses of 100 $\mathrm{mg} / \mathrm{kg}$ body weight also produced significant inhibition with average plate reaction time. Extracts of 100, 200 and 400 $\mathrm{mg} / \mathrm{kg}$ body weight and $100 \mathrm{mg} / \mathrm{kg}$ Papaverine and $100 \mathrm{mg} / \mathrm{kg}$ Phenylbutazone (positive control) significantly reduce the volume of paw oedema that is not dosedependent. There is also substantial inhibition of oedema of feet volume induced in extracts and in animals treated with medication. The results of this study indicate that Sauropus androgynus leaf extracts show activity in varying degrees of inflammation, pain and fever by activating cyclooxygenase, prostaglandin levels, especially PGE2, significantly increasing and their production triggers inflammation, pain and fever. The significant reduction, as well as the inhibitory effect of extracts on carrageenan-induced oedema foot volume, is an indication of the plant's antiinflammatory potential ${ }^{[35]}$.

Sauropus androgynus leaves extract at a concentration of $5 \mathrm{mg} / \mathrm{mL}$ is the lowest concentration that can inhibit the growth of bacterial strains after incubation when compared to controls. Chloramphenicol and gentamicin are used as standard antibiotics for Gram-positive and Gramnegative bacteria. The Kirby-Bauer disk 
diffusion method is used to determine the inhibition of bacterial growth by plant extracts. Six bacterial strains were used to test the antimicrobial activity of Sauropus androgynus. Among the six organisms investigated, three were Gram-positive, namely Bacillus cereus, Bacillus subtilis, Staphylococcus aureus and the other three were Gram-negative organisms, namely Escherichia coli, Klebsiella pneumoniae, and Salmonella typhimurium. Sauropus androgynous methanol leaf extract showed more inhibitory effect on Gram-positive bacteria when compared with ethanol extract. Methanol leaf extract also shows the best inhibitory effect on Gram-negative bacteria when compared with ethanol and water extracts ${ }^{[36,37]}$.

Sauropus androgynus leaf extract has anti-obesity activity. The extract can reduce body weight and eating index, increase stool weight and consistency comparable to orlistat, decrease retroperitoneal fat index, affect organ index by increasing the weight of the liver and testes. The best dose of Sauropus androgynus leaf extract in reducing body weight is $400 \mathrm{mg} / \mathrm{kg}$ body weight. Sauropus androgynus leaf extract with a dose of $400 \mathrm{mg} / \mathrm{kg}$ body weight has a bodyweight reduction activity of mice closer to the comparison (orlistat) than extract dose of $100 \mathrm{mg} / \mathrm{kg}$ body weight and $200 \mathrm{mg} / \mathrm{kg}$ body weight. S. androgynus leaf extract group 100, 200, and $400 \mathrm{mg} / \mathrm{kg}$ body weight had significant differences compared to the negative control group ( $\mathrm{p}$ $<0,05)$. The content of flavonoids in the leaves of Sauropus androgynus can reduce body weight through the mechanism of action to reduce food intake and reduce lipid accumulation in the liver ${ }^{[38]}$.

\section{CONCLUSION}

The Euphorbiaceae plants in Usada Taru Pramana have a variety of phytochemical constituents and correlate with its pharmacological activities. The secondary metabolite compounds found in the Euphorbiaceae plants are phenols, alkaloids, flavonoids, saponins, tannins and essential oils. Most of the Eupborbiaceae plants in Usada Taru Pramana have the potential for antiinflammatory, analgesic, and antibacterial. Further research needs to be carried out to explore other Euphorbiaceae plants species in Usada Taru Pramana to find compounds and other pharmacological activities to deal with various diseases in the community.

\section{CONFLICT OF INTEREST}

No conflict of interest in this paper. This paper was written independently without being affiliated by another party.

\section{ACKNOWLEDGMENT}

Authors would like to thanks all those who helped write this review article.

\section{REFERENCES}

1. Kemenkes RI. Kebijakan Obat Tradisional Nasional Tahun 2007. Jakarta: Kementerian Kesehatan Republik Indonesia; 2007.

2. Nala, N. Usada Bali. Denpasar: Penerbit PT. Upada Sastra; 1995.

3. Antari, N.P.U., I P.T. Suwantara, P.E.S.K. Yudha. Perbandingan Penggunaan Tanaman Obat Dalam Usada Taru Premana Pada Penduduk Banjar Sakah Desa Pemogan dan Banjar Kerta Desa Petang. Medicamento 2018; 4(1): 60-65.

4. Suryadarma, I.G.P. Konsepsi Kosmologi dalam Pengobatan Usada Taru Premana. Journal of Tropical Ethnobiology 2007; 2(1): 65-87.

5. Bijekar, S., M.C. Gayatri. Ethnomedicinal Properties of Euphorbiaceae Family-A Comprehensive Review. International Journal of Phytomedicine 2014; 6: 144-156.

6. Rahman, A.H.M., M. Akter. Taxonomy and Medicinal Uses of Euphorbiaceae (Spurge) Family of 
Rajashahi, Bangladesh. Research in Plant Sciences 2013; 1(3): 74-80.

7. Arsana, I N. Keragaman Tanaman Obat dalam Lontar "Taru Pramana" dan Pemanfaatannya untuk Pengobatan Tradisional Bali. Jurnal Kajian Bali 2019; 9(1): 241-261.

8. Putra, I.G.S. Taru Premana Khasiat Tanam-tanaman untuk Obat Tradisional. Denpasar: Penerbit PT. Upada Sastra; 1999.

9. Afjeiee, S.A., S.R. Tabatabaei, F. Fallah, F. Shiva, N.T. Zanjani, A. T. Fard, S. Adabian, M. Rahbar, R. Nourinia, A. Karimi. A Microbiological Study of Neonatal Conjunctivitis in Two Hospitals in Tehran, Iran. Asian Pacific Journal of Tropical Disease 2013; 3(6): 429-433.

10. Oliver, G.F., G.A. Wilson, R.J. Everts. Acute Infective Conjunctivitis: Evidence Review and Management Advice for New Zealand Practitioners. New Zealand Medical Journal 2009; 122(1298): 69-75.

11. Onocha, P.A., G.K. Oloyede, Q.O. Afolabi. Phytochemical Investigation, Cytotoxicity and Free Radical Scavenging Activities of Non-polar Fractions of Acalypha hispida (Leaves and Twigs). Experimental and Clinical Sciences International Online Journal for Advances in Science 2010; 10: 1-8.

12. Febriyanti, M., B.W. Sanjaya, Supriyatna, A. Diantin, A. Subarnas. Aktivitas Antioksidan Ekstrak Etanol dan Fraksi-Fraksi Daun Ekor Kucing (Acalypha hispida Burm. F) dengan Metode Penghambatan Reduksi Water Soluble Tetrazolium Salt-1 (WST-1). Fitofarmaka 2013; 3(2): 1-6.

13. Moningka, K.C., N.S. Kojong, S. Sudewi. Uji Aktivitas Antibakteri Ekstrak Daun Ekor Kucing (Acalypha hispida Burm. F.) terhadap Bakteri Staphylococcus auerus dan Escherichia coli secara In-Vitro. PHARMACON 2015; 4(3): 193-202.
14. Manikanta, B., P. R. Varma, V. Krishna, A.R. Kumar, K.M.S. Rathinam. Phytochemical Evaluation of Acalypha hispida, Acalypha nervosa, and Acalypha fruiticosa. Journal of Chemical and Pharmacetical Sciences 2014; 7(3): 197-199.

15. Okorondu, S.I., T.G. Sokari, M. M.O. Okorondu, E.C. Chinakwe. Phytochemical and Antibacterial Properties of Acalypha hispida Leaves. International Journal of Natural and Applied Sciences 2009; 5(2): 191-194.

16. Islam, S., S. Munira, S. Zaman, S.F. Koly, F.I. Sukorno, S. Ahammed, R. Hridoy. Estimation of Phytochemical, Antioxidant Screening Profile and Thrombolytic Activities of Methanolic Extract of Antidesma bunius L. Leaf. Horticulture International Journal 2018; 2(6): 358-363.

17. Islam, M.S., M.S. Ahammed, F.I. Sukorno, S. F. Koly, M.M Biswas, S. Hossain. A Review on Phytochemical and Pharmacological Potentials of Antidesma bunius. Journal of Analytical and Phamaceutical Research 2018; 7(5): 602-604.

18. Lintang, K., S. Panal, D. Aminah. Anti-inflammatory Activity of Ethanol and Fraction of Buni Leaves (Antidesma bunius L.) on White Rat in Carrageenan Induced Paw Inflammation. Asian Journal of Pharmaceutical Research and Development 2019; 7(5): 1-5.

19. Indrawati, I., A.F.M. Rizki. Potensi Ekstrak Buah Buni (Antidesma bunius L) sebagai Antibakteri dengan Bakteri Uji Salmonella thypimurium dan Bacillus cereus. Jurnal Biodjati 2017; 2(2): 138-148.

20. Jena, J., A.K. Gupta. Ricinus communis Linn: A Phytopharmacological Review. International Journal of Pharmacy 
and Pharmaceutical Sciences 2012; 4(4): 25-29.

21. Saini, A.K., R. Goyal, V.K. Gauttam, A.N. Kalia. Evaluation of Antiinflammatory Potential of Ricinus communis Linn Leaves Extracts and Its Flavonoids Content in Wistar Rats. Journal of Chemical and Pharmaceutical Research 2010; 2(5): 690-695.

22. Salman, I.S., H.M. Habeeb, I.A. Hassan, L.A. Jasaa, G.S. Saleh, Z.H. Helal. Effect of Ethanolic Extract of Ricinus communis L. on Some Biochemical Parameters and Hormones in Male Mice. Research Journal of Pharmaceutical, Biological, and Chemical Sciences 2017; 8(2): 848-854.

23. Taur, D.J., M.G. Waghmare, R.S. Bandal, R.Y. Patil. Antinociceptive Activity of Ricinus communis L. Leaves. Asian Pacific Journal of Tropical Biomedicine 2011; 1(2): 139141.

24. Tomar, N.S., M. Sharma, R.M. Agarwal. Phytochemical Analysis of Jatropha curcas L. during Different Seasons and Developmental Stages and Seedling Growth of Wheat (Triticum aestivum L.) as Affected by Extracts/Leachates of Jatropha curcas L. Physiology And Molecular Biology of Plants 2015; 21(1): 83-92.

25. Salim, M.N., D. Masyitha, A. Harris, U. Balqis, C.D. Iskandar, M. Hambal, Darmawi. Anti-inflammatory Activity of Jatropha curcas Linn. Latex in Cream Formulation on CD68 Expression in Mice Skin Wound. Veterinary World 2018; 11(1): 99-103.

26. Yulianto, S., Sunarmi. Aktivitas Antibakteri Ekstrak Daun Jarak Pagar (Jatropha curcas L) terhadap Staphylococcus epidermidis dan Staphylococcus aureus secara In Vitro. Jurnal Terpadu Ilmu Kesehatan 2018; 7(1): 60-66.
27. Srivastava, R., N. Soni. An Updated Review On Phytopharmacological Profile of Euphorbia tithymaloides (L.) Poit. The Pharma Innovation Journal 2019; 8(5): 109-115.

28. Matisui, E.D.S., L.A. Perrone, F.A.M. Araujo, A.L.M.D. Santos, J.M.V.M.D. Lucena. Pedilanthus tithymaloides (L.) Poit: Phytochemical Prospection and Antimicrobial Activity. Scientia Amazonia 2017; 6(3): 53-57.

29. Ghosh, A., D. Chattopadhyay, A. Mandal, S. Kaity, A. Samanta. Bioactivity Guided Isolation of Antiinflammatory, Analgesic, and Antipyretic Constituents from The Leaves of Pedilanthus tithymaloides (L.). Medicinal Chemistry Research 2013; 22: 4347-4359.

30. Dilpreet, K., K. Amandeep, K. Jaswinder. A Review on Aleurites moluccana. World Journal of Pharmacy and Pharmaceutical Sciences 2018; 7(6): 341-358.

31. Abd, S.O., R.R. Mohamad. Antibacterial Activity of Aleurites moluccana (Euphorbiaceae) Against Some Clinical Isolates. Research Journal of Biotechnology 2010; 5(3): 25-30.

32. Mpala, L.N., G.R. Chikowe, I.E. Cock. Aleurites moluccanus (I.) Willd. Extracts Inhibit the Growth of Bacterial Triggers of Selected Autoimmune Inflammatory Diseases. Pharmacognosy Community 2017; 7(2): 83-90.

33. Quintao, N.L.M., C.M. Silva, G.F. Silva, C.S. Antonialli, L.W. Rocha, R.M.L. Silva, A. Malheiros, M.M. Souza, V.C. Filho, T.M.B. Bresolin. Aleurites moluccana (L.) Wild Leaves: Mechanical Antinociceptive Properties of A Standardized Dried Extract and Its Chemical Markers. Evidence-Based Complementary and Alternative Medicine 2011; 11: 1-10.

34. Bunawan, H., S.N. Bunawan, S.N. Baharum, N.M. Noor. Sauropus 
androgynus (L.) Merr. Induced Bronchiolitis Obliterans: From Botanical Studies to Toxicology. Evidence-Based Complementary and Alternative Medicine 2015; 15: 1-7.

35. Selvi, S., A. Bhaskar. Antiinflammatory and Analgesic Activities of The Sauropus androgynus (L) Merr. (Euphorbiaceae) Plant in Experimental Animal Models. Der Pharmacia Lettre 2012; 4(3): 782785.

36. Ariharan, V.N., V.N.M. Devi, P.N. Prasad. Antibacterial Activity of Sauropus and Rogynous Leaf Extract Against Some Pathogenic Bacteria. Rasayan 2013; 6(2): 134-137.

37. Kuttinath, S., K.H. Haritha, R. Rammohan. Phytochemical Screening, Antioxidant, Antimicrobial, and Antibiofilm Activity of Sauropus androgynus Leaf Extracts. Asian Journal of Pharmaceutical and Clinical Research 2019; 12(4): 244250.

38. Patonah, E. Susilawati, A. Riduan. Aktivitas Antiobesitas Ekstrak Daun Katuk (Sauropus androgynus L. Merr) pada Model Mencit Obesitas. PHARMACY 2017; 14(2): 137-152. 